\title{
Comparison of Hemoglobin Concentration Before and After Trichuriasis Treatment with Albendazole among Primary School Children
}

\author{
Novreka P Sipayung1), Nurfida Arrasyid"), Ayodhia P Pasaribu3) \\ 1)Department Parasitology, Faculty of Medicine, HKBP Nommensen University, Medan \\ 2)Department Parasitology, Faculty of Medicine, Sumatera Utara University, Medan \\ 3)Department of Pediatrics,Sumatera Utara University, Haji Adam Malik Hospital, Medan
}

\begin{abstract}
Background: Trichuriasis is a soil transmitted helminth that causes anemia and growth disturbance in children. This study aimed to compare hemoglobin concentration before and after Trichuriasis treatment with albendazole among primary school children.

Subjects and Method: This was an experimental study with before and after quasi experiment design. This study was conducted at Medan Tembung Primary School, Medan, North Sumatera, from March to June, 2015. A total of 63 children were selected for this study. Blood sample was taken for hemoglobin concentration examination before and after the administration of albendazole. The treatment consisted of $400 \mathrm{mg}$ albendazole that was administered in single dose once a day for 3 days, both for single and mixed infection.

Results: The prevalence of Trichuriasis among the school children under study was 33.3\% (126/ 378 ), which was consisted of 37 children with single infection and 26 children with mixed infection. Albendazole increased hemoglobin concentration with mean $=11.88 \mathrm{~g} / \mathrm{dl} ; \mathrm{SD}=1.26$ before treatment and mean=12.53 $\mathrm{g} / \mathrm{dl} ; \mathrm{SD}=1.37$ after treatment, among children with single infection, and it was statistically significant $(\mathrm{p}=0.002)$. Albendazole increased hemoglobin concentration with mean= $11.69 \mathrm{~g} / \mathrm{dl} ; \mathrm{SD}=1.04$ before treatment and mean=12.36 g/dl; $\mathrm{SD}=1.06$ after treatment, among children with mixed infection, and it was statistically significant $(\mathrm{p}=0.001)$.

Conclusion: Albendazole is effective in increasing hemoglobin concentration among school children with anemia that is caused by Trichuriasis infection.
\end{abstract}

Keywords: helminthiasis, trichuriasis, hemoglobin, anemia, albendazole, school children

Correspondence:

Novreka Pratiwi Sipayung. Department Parasitology, Faculty of Medicine, HKBP Nommensen University, Medan. Email: eqa_efq@yahoo.com. Mobile: 085261145049.

\section{BACKGROUND}

WHO records that there are more than 1,5 billion people worldwide are infected by Soil Transmitted Helmint, 270 million of them are pre-school aged children and 600 million are school aged (Tekeste, 2013). Infection of roundworms type Ascaris lumbricoides is on the $1^{\text {st }}$ place with 1,2 billion people, whipworms Trichuris trichiura infects 795 million people, hook worm $\mathrm{Ne}$ cator americanus and Ancylostoma duodenale infect 740 million people worldwide
(Kirwan, 2009). In South East Asia, about 500 million people are infected, and school aged children are at the highest risk from getting infected (Vercruysse et al., 2011).

Approximately there are $70 \%$ children in Indonesia who suffer from worm infestation (Sutanto, 2008). Based on the data of Health Office of North Sumatera Province 2013 about $32 \%$ of North Sumatera population suffered from worm infestation, out of the data around $87 \%$ students of one of primary school in Deli Serdang suffered 
Indonesian Journal of Medicine (2016), 1(4): 201-208

https://doi.org/10.26911/theijmed.2017.02.01.08

from worm infestation, in which the prevalence of Trichuris trichiura was as much as $78.6 \%$.

Trichuris trichiura infection is one of the Soil Transmitted Helminth infection which endanger children's health by interfering iron status, growth, cognitive development, and disturbing immune response of the infected children (Keiser, 2008).

Losing too much iron during hemorrhage as the result of worm infestation may disturb the balance of iron, in which the more released iron compared to the incoming iron lead to anemia. Therefore the prevention and countermeasures effort is not only addressed the anemia but also should treat the disease that generates it. Albendazole is proven to be effective in treating various worm infestation diseases one of them is Trichuris trichiura that may lead to bleeding on intestinal mucosa and if it is ignored will cause anemia on children (Bamban, 2006; Janic, 2014)

It is important to give drug intervention first to avoid bias in this study and also the technique used in examining blood hemoglobin plays a very important role to obtain accurate result. Based on the facts, it is necessary to investigate further the comparison of hemoglobin concentration before and after trichuriasis treatment with albendazole on primary school students.

\section{SUBJECTS AND METHOD}

The study used clinical trial study in randomized open, conducted from March up to June 2015 in 067240 State Primary School, Village of Tembung, Medan Tembung Sub District, City of Medan. The study had been approved by Health Research Ethics Committee of Faculty of Medicine North Sumatera University and Haji Adam Malik Central General Hospital Medan.
As many as 378 children collected feces pots, and they were examined using Kato method in Parasitology Laboratory of North Sumatera University, Medan. Data on social demography and behavior were collected by using questionnaires, filled out by parents as well as interview and observation. Examination of hemoglobin concentration was directly conducted in the research location.

Sample of the study was the accessible population that met the inclusive criteria which were the entire students of class 1-6 who suffered from trichuriasis either mono infection or mixed followed by good nutrition status. Exclusive criteria were students who did not return their feces pot, were absent, refused to provide blood sample, suffered from chronic illnesses, consumed medication/ supplement that might interfere hemoglobin concentration. As many as 63 students who met the inclusive criteria and provided blood sample for hemoglobin concentration examination, afterward treatment with $400 \mathrm{mg}$ albendazole was given for 3 consecutive days and monitored for 90 days, continued with hemoglobin concentration examination all over again.

\section{RESULTS}

The result of feces examination found that 256 students (67.7\%) suffered from worm infestation among others were 124 students who positively suffered from mono infection of A. lumbricoides, 51 students positively suffered from mono infection of $T$. trichiurat, 75 students were positive with $A$. lumbricodes and T. trichiura, 2 students were positive with A.lumbricodes and hook worm, 4 students were positive with $T$. trichiura and hook worm. Students who became research sample were those who suffered from mono infection of $T$. trichiura and mixed infection of T. trichiura and $A$. 
lumbricoides. There were only 63 students who met the inclusive criteria in which 37 students suffered from $T$. trichiura and 26 suffered from mixed infection (A. lumbricoides and $T$. trichiura). The entire respondents were treated with single dose of 400 mg albendazole 3 consecutive days. After the treatment, the whole respondents of the study were followed up for 90 days and underwent hemoglobin concentration examination once again. Prevalence of worm infestation in Medan Tembung sub district was $67.7 \%$, with ascariasis prevalence was 48.44 $\%$, mono trichuriasis prevalence was 19.92 $\%$, and mixed trichuriasis prevalence was $29.3 \%$.

\section{Table 1.Data of basic characteristics}

\begin{tabular}{|c|c|c|}
\hline Characteristics & Mono Trichuriasis $(n=37)$ & Mixed Trichuriasis $(n=26)$ \\
\hline \multicolumn{3}{|l|}{ Gender Types } \\
\hline Male, n (\%) & $17(45.9)$ & $14(53.8)$ \\
\hline Female, n (\%) & $20(54.1)$ & $12(46.2)$ \\
\hline Age (years),mean(SD) & $9.9(1.5)$ & $9.4(1.9)$ \\
\hline Weight (kg), mean(SD) & $27(6.0)$ & $25.6(6.9)$ \\
\hline \multicolumn{3}{|l|}{ Infection intensity, $\mathrm{n}(\%)$} \\
\hline Mild & $37(100)$ & $19(76.0)$ \\
\hline Moderate & $\mathrm{o}(0.0)$ & $7(24.0)$ \\
\hline Severe & $0(0.0)$ & $\mathrm{o}(0.0)$ \\
\hline \multicolumn{3}{|l|}{ Fathers' occupation, n (\%) } \\
\hline Labors & $5(13.5)$ & $4(15.4)$ \\
\hline Pedicab drivers & $4(10.8)$ & $1(3.8)$ \\
\hline Farmers & $2(5.4)$ & $3(11.5)$ \\
\hline Civil servants & $3(8.1)$ & $3(11.5)$ \\
\hline Self employed & $18(48.6)$ & $10(38.5)$ \\
\hline Others & $5(13.5)$ & $5(19.2)$ \\
\hline \multicolumn{3}{|c|}{ Mothers' occupation, n (\%) } \\
\hline Labor & $7(18.9)$ & $3(11.5)$ \\
\hline Pedicab drivers & $0(0.0)$ & $0(0.0)$ \\
\hline Farmers & $\mathrm{o}(0.0)$ & $1(3.8)$ \\
\hline Civil Servants & $1(2.7)$ & $1(3.8)$ \\
\hline Self employed & $15(40.5)$ & $14(53.8)$ \\
\hline Others & $14(37.8)$ & 7 (26.9) \\
\hline \multicolumn{3}{|l|}{ Fathers' education, $\mathrm{n}(\%)$} \\
\hline Uneducated & $1(2.7)$ & $\begin{aligned} 2(7.7) \\
5(102)\end{aligned}$ \\
\hline Primary & $6(16.2)$ & $5(19.2)$ \\
\hline Junior High School & $4(10.8)$ & $4(15.4)$ \\
\hline High School & $22(59.5)$ & $13(50.0)$ \\
\hline University & $4(10.8)$ & $2(7.7)$ \\
\hline \multicolumn{3}{|l|}{ Mothers' education, n (\%) } \\
\hline Uneducated & $2(5.4)$ & $0(0.0)$ \\
\hline Primary & $4(10.8)$ & $7(26.9)$ \\
\hline Junior High School & $8(21.6)$ & $4(15.4)$ \\
\hline High School & $21(56.8)$ & $15(57.7)$ \\
\hline University & $2(5.4)$ & $0(0.0)$ \\
\hline
\end{tabular}

From the basic characteristics of research respondents in table 1 that trichuriasis was likely suffered more by female that was 22 children (31.7\%), whereas mixed tri- churiasis was likely suffered more by male that was 14 children (22.2\%). From respondents who suffered from mono trichuriasis and mixed trichuriasis it was obtained that 
the mean of children's age was 9.89 and 9.43 years, with the range of the age was $5^{-}$ 12 years. From the table it was also seen that the mean of children's weight who suffered from mono trichuriasis and mixed trichuriasis was $27 \mathrm{~kg}$ and $25.56 \mathrm{~kg}$

Intensity of infection of the entire samplewasdominated by mild intensity that was 88.9\% whereas moderate intensity was $11.1 \%$.
There was no severe intensity of infection degree found either on mono trichuriasis or mixed trichuriasis. Most of parents were self employed in which Father was $44.4 \%$ whereas Mother was $46 \%$, meanwhile the most dominant parents education was High School Level in which Father was $55.6 \%$ whereas Mother was 57.1\%.

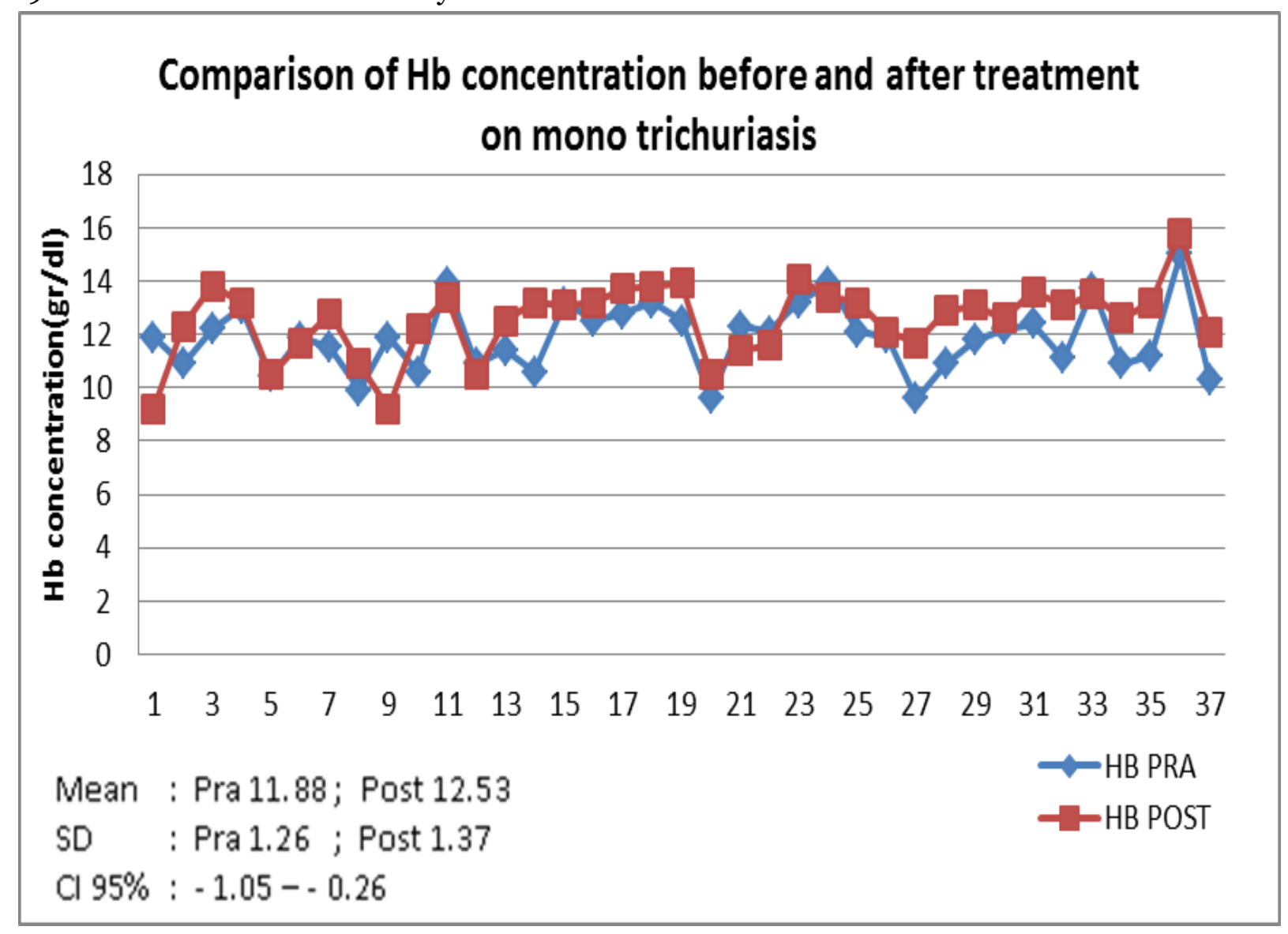

Picture 1. Chart on hemoglobin concentration comparison before and after the treatment on the sufferers of mono trichuriasis

In Picture 1 it can be seen that the means of hemoglobin concentration before and after treatment on children with mono trichuriasis are $11.88 \mathrm{~g} / \mathrm{dl}$ and $12.53 \mathrm{~g} / \mathrm{dl}$ $(\mathrm{p}=0.002)$. It shows meaningful difference between the mean of hemoglobin concentration before and after treatment on mono trichuriasis.
In Picture 2 the means of hemoglobin concentration before and after treatment on children with mixed trichuriasis are 11.69 and $12.36 \mathrm{~g} / \mathrm{dl}(\mathrm{p}=0.001)$. It shows meaningful difference between the mean of hemoglobin concentration before and after treatment on mixed trichuriasis (A.lumbricoides and T.trichiura). 


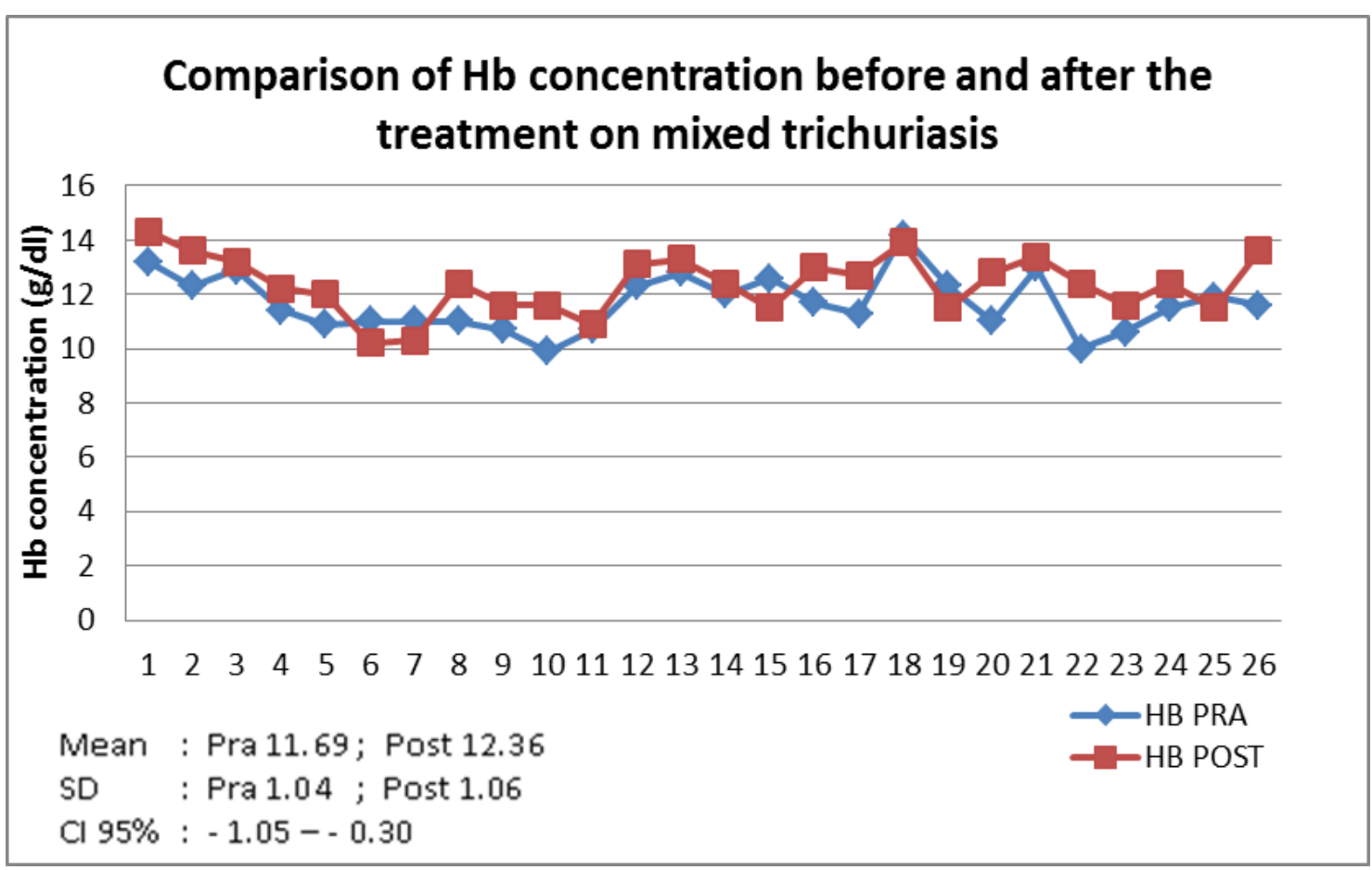

Picture 2. Chart on hemoglobin concentration comparison before and after the treatment on the sufferers of mixed trichuriasis

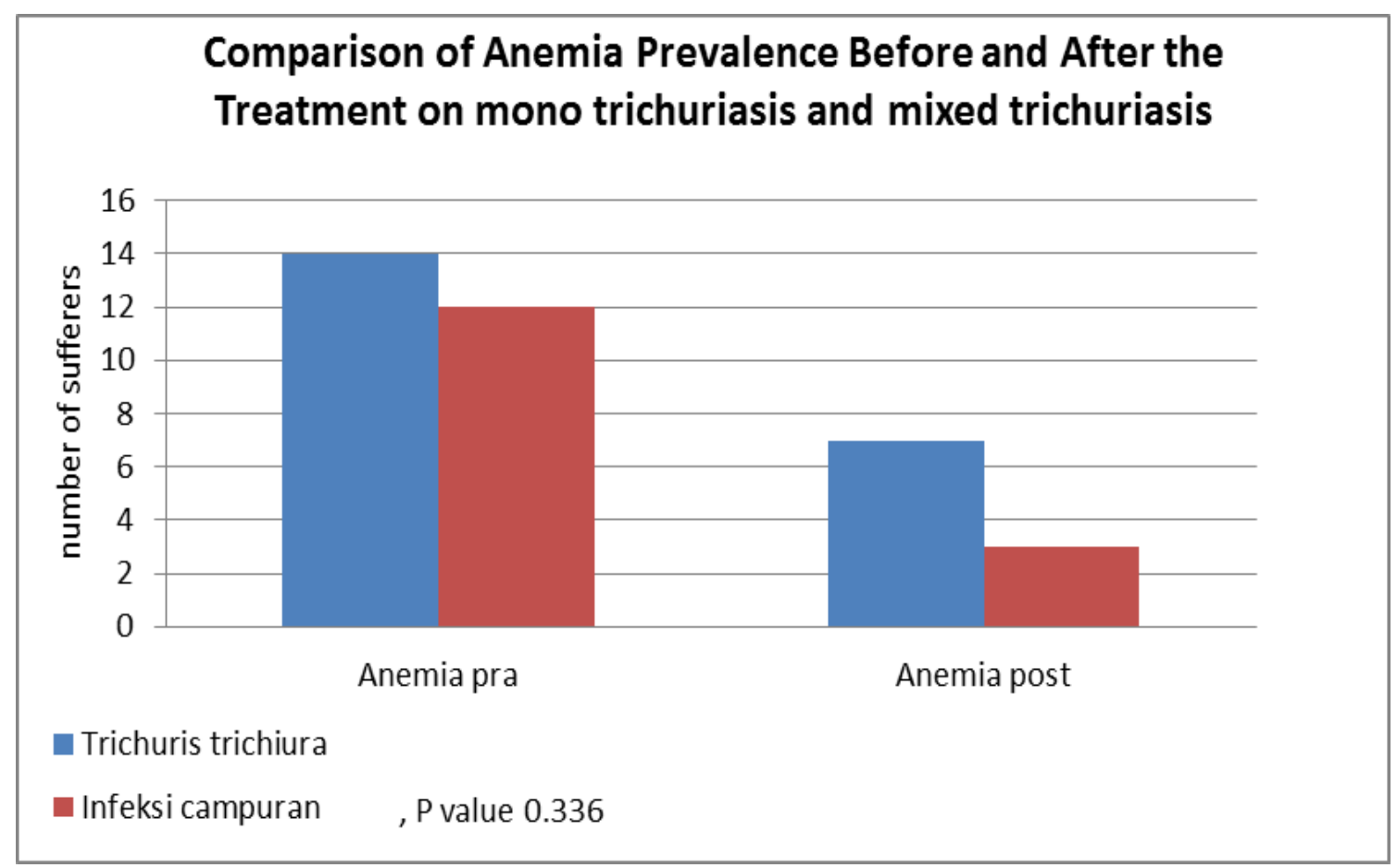

Picture 3. Chart on anemia prevalence comparison before and after the treatment on mono trichuriasis and mixed trichuriasis 
Indonesian Journal of Medicine (2016), 1(4): 201-208

https://doi.org/10.26911/theijmed.2017.02.01.08

In Picture 3 above it is observed that anemia prevalence on mono trichuriasis before treatment is $\mathbf{2 2 . 2 \%}$ (14 people) however after the treatment was administered, prevalence is reducing to $11.1 \%$ (7 people). Meanwhile anemia prevalence on mixed trichuriasis before treatment was 19\% (12 people) however after the treatment was administered, prevalence is reducing to $4.8 \%$ (3 people). From the result of analysis test it is observed that there is difference between anemia prevalence before and after trichuriasis treatment with albendazole however it is insignificant both on mono trichuriasis $(\mathrm{p}=0.344)$ as well as mixed trichuriasis $(\mathrm{p}=0.336)$

\section{DISCUSSION}

Prevalence of children who suffered worm infestation in this study was found as much as $67.7 \%$. It had reduced compared to the study in 2008 by Yunus that was $73 \%$. Prevalence of single Trichuris trichiura was as much as $19.92 \%$, lower than what Yunus found in 2008 that was $25.94 \%$. For worm infestation Trichuris trichiura and Ascaris lumbricoides as much as $29.3 \%$, was also lower than the result obtained in 2008 as much as $36.33 \%$. In broad outline researchers obtained the lower prevalence of intestinal worm infestation compared to the previous study by Yunus in 2008 that was $73 \%$. It is possible since from time to time society's knowledge is improving, and also because of worm infestation treatment on school students (Yunus, 2008).

However even though there was a prevalence reduction from 2008 -2015, the numbers of incident was still quite high that was above 50\%. The remaining high prevalence of worm infestation on school aged children was lead by low health standard and high frequency of outdoor activities that made children are prone of worm infestat- ion transmission. Students of 067240 State Primary School, Medan Tembung Sub District often did not put on shoes during classes and even they did activities outside the class barefoot. The environment in the schools surroundings were mostly soil and sand, that became places to proliferate the intestinal worms that might cause infection. Children's less awareness to wash their hands before eating also became one of the ways for those worms to get into their bodies. Chaudhry et al (2004) reports that high prevalence of worm infestation is related to poverty, personal hygiene, bad environment, insufficient healthcare service, insufficient sanitation facilities or latrine and clean water source.

Meanwhile a study conducted by Angraini et al., in 2005 found that the prevalence of mixed worm infestation is quite high. In her study it is found that mono infection of Ascaris lumbricoides has prevalence which is almost as high as mixed infection of Ascaris lumbricoides and Trichuris trichiura. Smith et al (2001) obtains in his study that the prevalence of Ascaris lumbricoides and Trichuris trichiuramasing is respectively $45 \%$ and $38 \%$. About a quarter (25.8\%) of the research respondents are infected by mixed infection of Ascaris lumbricoides and Trichuris trichiura. In South India, Nallam et al (1998) finds the same result in his study. Whereas the study shows the prevalence of mixed infection of Ascaris lumbricoides and Trichuris trichiura is about one third (29\%) of the numbers of research respondents. It shows that there is a positive association between infection of Ascaris lumbricoides and Trichuris trichiura. The large number of Ascaris lumbricoides infestation has significant association with Trichuris trichiura. The high prevalenceofmixed infection is generated by the same 
transmission pathways toward human that is through feces and oral.

In the study there was significant difference between hemoglobin concentration before and after the treatment on each type of worm infestation. Greenberg et al., finds that there is an association between infection of Trichuris trichiura with the low hemoglobin concentration however there is no association with iron deficiency. Nallam (1998) finds that Ascaris lumbricoides infection does not contribute in generating anemia, however Blumenthal (1976) in Lousiana reports that ascariasis affects nutrition status on children and almost $50 \%$ of his research subjects suffer from anemia and $40 \%$ of them have less sufficient transferrin saturation. Robertson et al (1992) finds that children who are infected with severe trichuriasis or mixed infection of Trichuris trichiura and hook worm have low hemoglobin concentration. Stoltzfus et al., reports that infection of Ascaris lumbricoides is related to anemia however it is not related to intestinal hemorrhage.

The study showed that the administration of single dose of $400 \mathrm{mg}$ albendazole was beneficial in healing the infection of $T$. trichiura so that the hemoglobin concentration was increasing. It was proven in which there are significant statistics difference in the concentration of hemoglobin $(\mathrm{p}<0.005)$. Meanwhile there was difference in anemia prevalence before and after the treatment howeverit was statistically insignificant. The study was similar with Robertson. In the study conducted by Oguntibeju (2003) it is elaborated that worm infestation has an association with the hematology index alteration. The study still had a lot of drawbacks therefore it needs further hematology examination which is more comprehensive to determineother possible causes ofanemia. Con- sequently, researcher assumed that mono trichuriasis and mixed trichuriasis were the only causes of anemia happen to the research subjects although other factors can't be disregarded.

Theresearch showed that there was significant difference in the hemoglobin concentration before and after $400 \mathrm{mg}$ albendazole treatment in single dose once in every day for 3 days in a row on children who suffered from mono as well as mixed trichuriasis, whereas there was no significant association between anemia prevalence and the type of worms infestation. The administration of single dose of $400 \mathrm{mg}$ albendazole for 3 consecutive days was beneficial in suppressing the incidents percentage of trichuriasis so that children are prevented from anemia and children's cognitive will be increasing.

\section{REFERENCE}

Anggraini R, Dimyati Y, Bidasari L, Pasaribu $\mathrm{S}$, Lubis CP (2005). Association between Soil Transmitted Helminthiasis and Haemoglobin Concentration in Primary School Children. Paediatrica Indonesiana 45: 1-2. Available from http://repository.usu.ac.id/handle/12 3456789/18132.

Bambang PH, Sutaryo, Ugrasena IDG (2006). Buku Ajar Hematologi Onkologi Anak. Cetakan kedua. Badan Penerbit IDAI: 30-35.

Blumental DS, Schultz MG (1976). Effects of Ascaris infection on nutriational status in childrean. Am J Trop Med Hyg 25: 682-90.

Chaudhry ZH, Fazal M, Malik MA (2004). Epidemiological factors affecting prevalence of intestinal parasites in children of Muzaffarabad district. Pakistan J Zool 36: 267-271. 
Indonesian Journal of Medicine (2016), 1(4): 201-208

https://doi.org/10.26911/theijmed.2017.02.01.08

Dinas Kesehatan Provinsi Sumatera Utara. 2013. Profil Kesehatan Provinsi Sumatera Utara.

Greenberg ER, Cline BL (1979). Is trichuriasis associated with iron deficiency anemia Am J Trop Med Hyg 28: 7702.

Janice VN, Vicente Y, Belizario Jr, Florencia GC (2014). Determination of soil-transmitted helminth infection and its association with hemoglobin levels among Aeta school children of Katutubo Village in Planas, Porac, Pampanga Philippine Science Letters 7 (1).

Kirwan P, Asaolu SO, Abiona TC, Jackson AL, Smith HV, Holland CV (2009). Soil transmitted helminth infections in Nigerian children aged 0-25 months. Journal of Helminthology: 1-6.

Nallam NR, Paul I, Gnanamani G (1998). Anemia and hypoalbuminemia as an adjunct to soil transmitted helminthiasis among slum school children in Visakhapatnam. South India, Asia Pasific J Clin Nutr 7: 164-169.

Oguntibeju OO (2003). Parasitic infection and anemia: the prevalence in a rural hospital setting. JIACM: 210-212.

Robertson LJ, Crompton DWT, Nesheim MC (1992). Hemoglobin concentrarion and concomitant infections of hookworm and Trichuris trichiura in Panamanian primary school children. Transactions of the Royal Society of Tropical Medicine and Hygiene.

Smith HM, De Kaminsky RG, Niwas S, Soto RJ, Jolly PE (2001). Prevalence and intensity of infections of Ascaris lumbricoides dan Trichuris trichiura and associated sociodemographic variables in four rural Honduran communities. Mem Inst Oswaldo Cruz, Rio de Janeiro 96: 303-14.

Stoltzfus RJ, Albonico, Chwaya M, Savioli L, Tielsch J, Schulze K (1996). Hemoquant determination of hookworm related blood loss and its in iron deficiency in African children. Am J Trop Med Hyg 55: 399-404.

Sutanto I, Ismid SI, Sjarifuddin KP, Sungkar S (2008). Parasitologi Kedokteran. Edisi Keempat. Jakarta: Balai Penerbit FK UI. Cetakan 2: 22.

Tekeste Z, Belyhun Y, Gebrehiwot A, Moges B, Workineh M, Ayalew G (2013). Epidemiology of intestinal schistosomiasis and soil transmitted helminthiasis among primary school children in Gorgora, Northwest Ethiopia.Asian Pac J Trop Dis 3(1): 61-64.

Vercruysse J, Behnke JM, Albonico M, Shaali M, Angebault C, Bethony MJ (2011). Assessment of the antihelmintic efficacy of albendazole in school children in seven countries where soil-transmitted helminths are endemic. PLoS Negl Trop Dis 5 .

Yunus R (2008). Keefektifan Albendazole Pemberian Sekali Sehari Selama 1,2 Dan 3 Hari Dalam Menanggulangi Infeksi Trichuris trichura pada Anak Sekolah Dasar di Kecamatan Medan Tembung. Medan. Available from http: //repository.usu.ac.id/handle/123456 $789 / 6244$. 